\title{
Multistakeholder policy formulation and action planning for urban agriculture in Lima, Peru
}

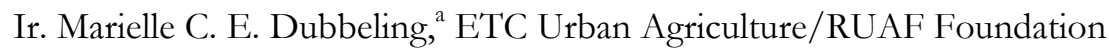 \\ Gunther Merzthal ${ }^{\mathrm{b}}$ and Noemi Soto, ${ }^{\mathrm{c}}$ IPES/RUAF Foundation
}

Submitted 23 July 2010 / Accepted 8 November 2010 / Published online December 2010

Citation: Dubbeling, M., Merzthal, G., \& Soto, N. (2010, Fall). Multistakeholder policy formulation and action planning

for urban agriculture in Lima, Peru. Journal of Agriculture, Food Systems, and Community Development, 1(2): 145-154.

doi:10.5304/jafscd.2010.012.010

Copyright (C) 2010 by New Leaf Associates, Inc.

\begin{abstract}
Multistakeholder processes are increasingly considered to be an important element of policy design, action planning, and implementation. By involving a broad base of stakeholders, municipal authorities are more likely to develop policies and programs that will meet the needs of both the municipality and its constituents, and are thus more inclusive and successful in their implementation. Because of its multisectoral character, with impacts on land use planning, health, food security, and economic development, among others, urban agriculture development calls for the involvement of multiple stakeholders, including individuals, and groups and organizations from both nongovernmental as well
\end{abstract}

\footnotetext{
a Corresponding author: Senior Adviser Urban Agriculture, ETC Urban Agriculture/RUAF Foundation, Kastanjelaan 5, P.O. Box 64, Leusden, 3830 AB The Netherlands; m.dubbeling@etcnl.nl

b Regional Coordinator for Latin America and the Caribbean, IPES/RUAF Foundation, Calle Audiencia 194 San Isidro, Lima 27 - Perú; gunther@ipes.org.pe

c IPES/RUAF Foundation, Calle Audiencia 194 San Isidro, Lima 27 - Perú; noemi@ipes.org.pe
}

as governmental sectors. In doing so, requirements for setting up and managing successful multistakeholder processes, including sufficient financial resources, time, training, and creating mutual trust, have to be taken into account. This article will illustrate the multistakeholder process taken and lessons learned by the district of Villa María del Triunfo in Lima, Peru. It shows how such processes can result in urban agriculture becoming institutionalized, while at the same time providing concrete benefits for urban producers (such as enhanced food security and employment) and the city as a whole. Linking project implementation to policy formulation, including urban agriculture in land use planning, providing it with an institutional home, and regular monitoring and empowerment of urban farmer organizations prove to be key elements to ensure the sustainability and consolidation of an urban agriculture policy and program beyond the period of a given political administration and to plan for its future up-scaling.

\section{Keywords} urban agriculture, policy formulation, strategic planning, Lima, Peru 


\section{The need for multistakeholder policy formulation and action planning on urban agriculture}

Urban agriculture is increasingly recognized for its potential to contribute to various urban policy goals, including food security, poverty alleviation, local economic development, environmental management, and community development (Baker, 2008; Mougeot, 2005; Redwood, 2009; van Veenhuizen, 2006). Once governmental authorities and support institutions (public, non-profit and private) better understand the benefits and risks associated with urban agriculture, they often seek to facilitate its development by means of proactive policies and intervention strategies that enhance the socioeconomic and environmental benefits of urban agriculture, while controlling and regulating the practice in order to reduce potential associated health and environmental risks (Cole, Lee-Smith, \& Nasinyama, 2008; Dubbeling, De Zeeuw, \& van Veenhuizen, 2010).

City governments aiming to promote and/or regulate certain types of urban agriculture can apply various policy instruments and intervention strategies to do so. Formulating and implementing effective policies, however, will require involving a wide range of often disconnected actors or stakeholders. ${ }^{1}$ Urban agriculture takes place in a multisectoral environment, touches on a large number of urban management areas (e.g., land-use planning, environmental and waste management, economic development, public health, and social and community development), and involves a large diversity of systems and related actors (input provision, vegetable production, aquaculture, livestock production, processing, and marketing).

\footnotetext{
${ }^{1}$ For our purposes, the term "urban agriculture stakeholders" refers to individuals, groups, or organizations, including governments, involved in urban agriculture activities, such as the production, processing, marketing, or distribution of food, and disposal of food wastes, etc., within or near urban areas. Urban agriculture stakeholders can be defined as all those who have an interest—sometbing at stake — in urban agriculture. This includes people and organizations who influence a decision, or can influence it, as well as those affected by it.
}

Urban agriculture can only be successfully integrated into urban policies and planning if coordination between various government levels, structures, and departments is improved and can ensure that land-use planning is coordinated with community development and health authorities for the benefit of food production (Redwood, 2010). Such integration also requires that local producer and community groups, who tend to be the city's most excluded groups, are recognised as legitimate actors in urban management and decision-making. This in order to get support in becoming more professional and accountable for their trade, and in increasing their contribution to the local economy, or to the landscape of community organizations through partnerships and alliances with other stakeholders (Mougeot, 2005).

When a government collaborates-preferably from an early stage-with other stakeholders such as citizens, farmers, civic organizations, private-sector companies, and other governmental entities in the preparation, implementation, and evaluation of policies and related action plans, we speak of multistakeholder policy and action planning (MPAP). Multistakeholder processes, sometimes called "partnerships," have been widely promoted in different sectors of development, e.g. water and catchment management, rural development, and information and communication management. They are becoming a very popular mode of involving civil society in debates and decisionmaking on resource management, as they provide a negotiating space for a diversity of interests (Warner 2007).

\section{Characteristics of multistakeholder processes}

The Multistakeholder Policy formulation and Action Planning (MPAP) approach was developed in the 1990s in the context of the UNEP Local Agenda 21 programs $^{2}$ and the UN-HABITAT city

\footnotetext{
${ }^{2}$ Local Agenda 21 is "a local-government-led, communitywide, and participatory effort to establish a comprehensive action strategy for environmental protection, economic prosperity and community well-being in the local jurisdiction or area. This requires the integration of planning and action
} 
consultation strategies. ${ }^{3}$ It is normally built around the following phases (UN-HABITAT and UNEP, 1999):

1. diagnosis, assessment and stakeholder inventory;

2. consultation to confirm political support and consolidate stakeholder participation;

3. joint strategy development and action planning;

4. implementation;

5. follow-up and consolidation; and

6. integrated monitoring and evaluation.

If a participatory and multistakeholder approach is chosen, action plans and policies are formulated and implemented in collaboration with and interaction between a local (or national) government and other relevant stakeholders, including citizen groups, community-based organizations (CBOs), nongovernmental organizations (NGOs), municipal departments, regional or national governmental organizations, credit institutions, private enterprises, and others. The ideal of such inclusive participation, however, may have different levels of significance that vary according to each phase of food (or urban agriculture) policy development. While inclusive participation may be particularly critical during early phases of identifying problems and proposing solutions, it may be less critical during implementation phases, where different

across economic, social and environmental spheres. Key elements are full community participation, assessment of current conditions, target setting for achieving specific goals, monitoring and reporting." See http://www.gdrc.org/ uem/la21/la21.html

${ }^{3}$ City consultations "bring together local authorities, the private sector, community representatives and other stakeholders within a city to discuss specific issues and solutions to key urban problems. They are a continuous process of dialogue among stakeholders and the city government." See http://www.unhabitat.org/content.asp? typeid $=19 \&$ catid $=374 \&$ cid $=186$

\section{Benefits of applying a participatory and multi- stakeholder approach include the following} (Hemmati, 2002; Partners and Propper, 2004):

- It contributes to more participatory governance, encourages public-private partnerships, and helps overcome distrust and bridge the gap between citizen groups and the government.

- It improves the quality of the diagnosis of the actual situation and the decision-making on the courses of action needed. This comes about through a better understanding of priority issues and the needs of different stakeholders involved, and a better linking of different sources of knowledge, information, and expertise.

- It improves the likelihood of success and sustainability of implementation through enhanced acceptance and ownership of the policy, improved mechanisms and processes for coordinating the implementation, and by mobilizing and pooling scarce human, technical, and financial resources.

- It strengthens the problem-solving and political lobbying capacities of the participating institutions, and contributes to the empowerment of citizens' groups (in this case, especially, resource-poor urban producers).

mechanisms of collaboration and communication can be put in place for different actors and groups (Mendes, 2008).

A major aim of applying the multistakeholder approach is to build participatory and democratic governance in cities. Multistakeholder policy and planning processes are based on principles of participation, ownership, and commitment, mutual trust and collaboration (in planning, decisionmaking, and control). They are thus in fact political processes through which power relations are redefined and, if well organized, lead to a more participatory governance and increased participation of civil society in decision-making. Challenges, however, include the following (Faysse, 2006, Hemmati 2002): 
- The process requires skilled facilitators and sufficient financial means.

- It may need more time than conventional approaches, not the least of which is to allow for changes that may be required in institutional cultures.

- It may also lead to an undue increase in the influence of some stakeholders, for example those who have a higher capacity to actively participate in the process and to convince other stakeholders.

- It may prove difficult to build true participation among stakeholders who may never have worked together, had conflicts in the past, hold strongly differing views on the key issues at stake, or are not interested in new forms of collaboration and management.

The duration of the MPAP process varies widely, influenced by the degree of commitment of the local partners (especially the local government), the complexity of the issues, and other factors. Sometimes tangible results become visible within a relatively short time period, whereas in other cases it may take quite some time before things start falling into place.

Organizations like the international network of Resource centres on Urban Agriculture and Food Security (RUAF), the former Urban Management Programme supported by UNDP and UNHABITAT, and the UN-FAO have supported various cities in multistakeholder planning and policy formulation on urban agriculture. In the Democratic Republic of the Congo, for example, FAO has provided assistance to support a municipal multistakeholder consultation platform (MCP). Its mandate is to moderate and make recommendations on the key issues related to sustainable urban and peri-urban agriculture and more specifically to make decisions in the area of land and water use for urban agriculture activities. In addition, MCP acts as a pressure group with the urban planners to fully integrate green spaces for urban agriculture activities into a city development plan and to make best use of recycled waste materials. Stakeholders include central government authorities, public health and education representatives, municipal authorities, representatives of producer associations, inputs suppliers, land tenure authority, water distribution and use managers, NGOs, and microfinance operators (UN FAO, 2008).

Through its Cities Farming for the Future program, RUAF has supported multistakeholder policy in action planning in 21 cities around the world. In the following case example, one such experience with implementing a MPAP on urban agriculture in Lima, Peru, is described in further detail and the results illustrated with some concrete examples. This MPAP in Lima was supported by RUAF's regional partner, IPES (IPES-Promoción del Desarrollo Sostenible), which participated in all steps of the process. Regular process documentation and monitoring was applied as an integral part of the approach, using quarterly documentation and monitoring reports, regular team meetings, and field visits. Reports were developed on main steps in the process (e.g., for the situation analysis, a City Strategic Agenda was developed ${ }^{4}$ ). This case study is the result of personal experience of the supporting IPES/RUAF team and a systematic review of all documents produced.

\section{The case of Lima, Peru}

Agriculture is practiced widely in the low-income districts of Lima, Peru. Yet despite the significant contribution urban and peri-urban agriculture make to household incomes and food security, this sector of the economy was little known or understood until a couple of years ago. Farming was absent from the municipal organization and planning, and the voices of local producers were unheard (CIP, 2007).

The district of Villa María del Triunfo is located at the southern outskirts of Lima and has a popula-

\footnotetext{
${ }^{4}$ The City Strategic Agenda can be downloaded from http:/ $/$ www.ipes.org/index.php?option $=$ com content\&view $=$ $\underline{\text { article } \& \text { id }=203 \& \text { Itemid }=125}$
} 


\section{Figure 1. Map showing Peru and Lima}

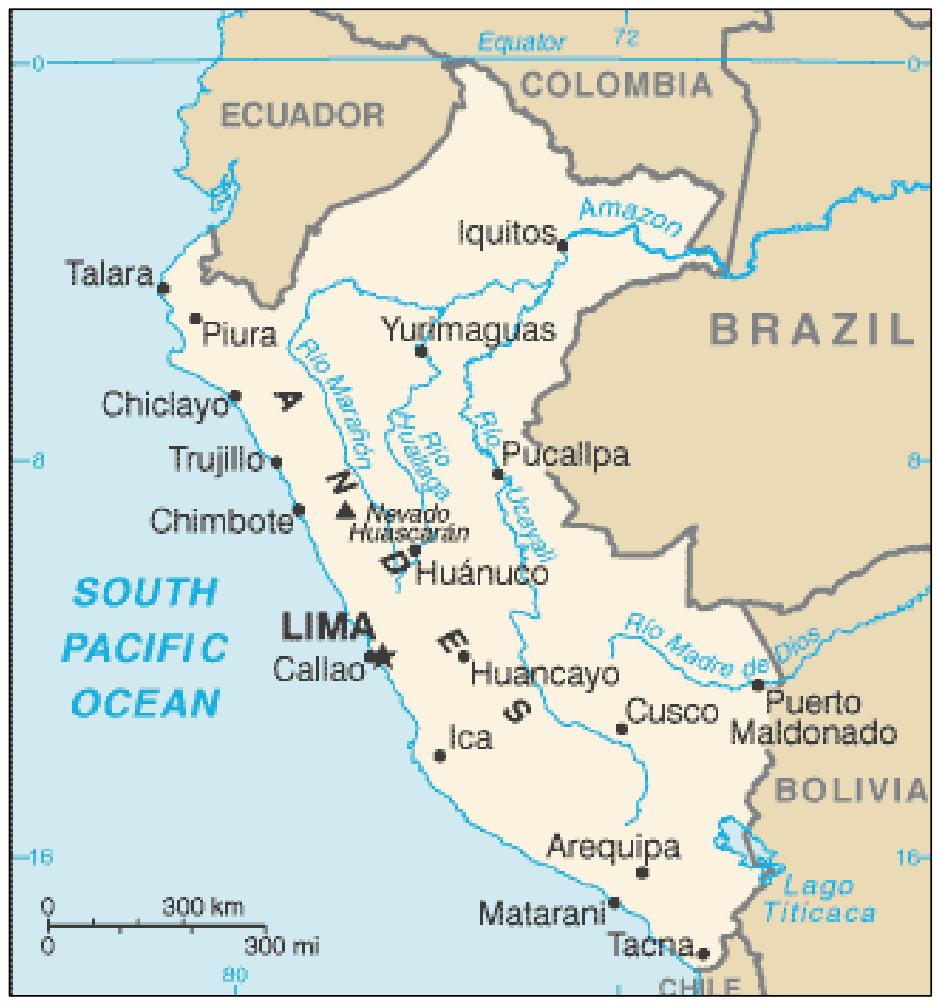

Source: http://www.geographyiq.com/countries/pe/Peru_map_flag_ geography.htm; () 2002-2010 GeographylQ.com. All rights reserved.

tion of almost 360,000 inhabitants (figures 1 and 2). Over $57 \%$ of the residents live in poverty, and $15 \%$ suffer from malnutrition, with children most affected (INEI, 2005). In response, the municipality started an urban agriculture program in 1999 to improve urban food security. The authorities of Villa María del Triunfo incorporated urban agriculture in the city's Integrated Development Plan (2001-2010) and created a Municipal Urban Agriculture and Environmental Protection Programme (PAU). This urban agriculture program, however, did not provide good guidelines for implementation as it was not based on a solid analysis of urban agriculture in the city. Nor did it respond sufficiently to the real needs and priority issues of the different groups of urban producers farming in the city since they lacked participation in the process. Finally, human and financial resources from the
Figure 2. Map showing the location of the district of Villa María del Triunfo-VMT (red) in Lima (light beige)

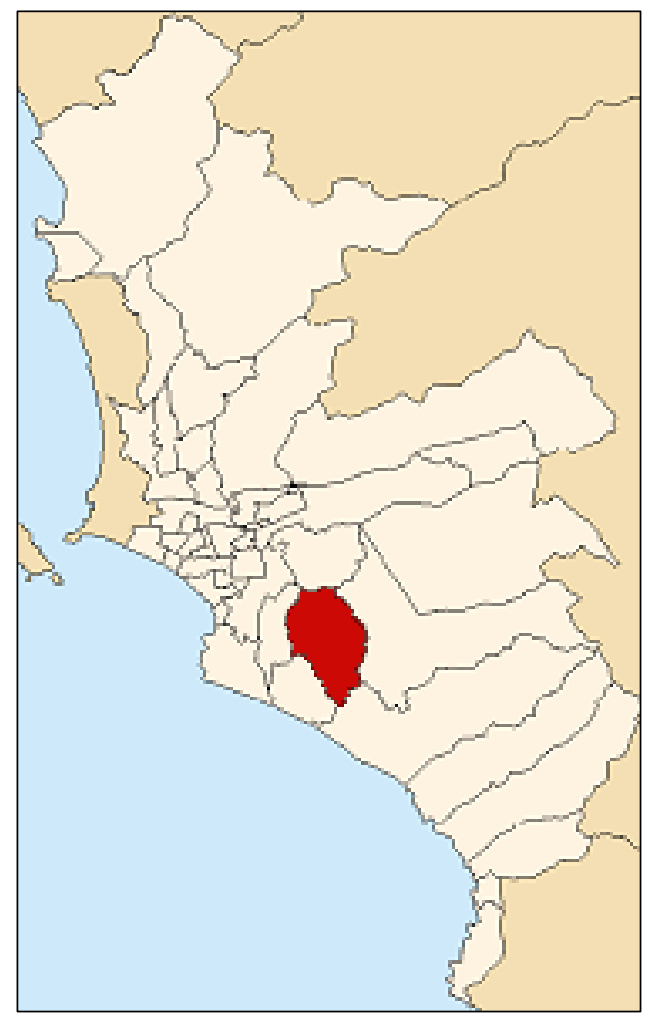

Source: Map by AgainErick from http://en.wikipedia. org/wiki/File:Map of Lima highlighting Villa Mar\%C3\%ADa_del_Triunfo.PNG

municipality were scarce and limited in implementing the proposed program (Merzthal, 2006).

In order to fill the gaps and flaws identified in their urban agriculture program, the municipality of Villa María del Triunfo, with the support of IPES/ RUAF, conducted a multistakeholder policy formulation and action planning process from 2005 to 2007. Action-research was implemented to (a) analyze the presence and potential contribution of urban agriculture to household livelihoods and the urban environment in the district, (b) develop a better understanding among decision-makers and other actors about the significance of local food production and its potential impacts, and (c) revise its urban agriculture policy and formulate a strategic action plan for urban agriculture. 
They built their multistakeholder process on experiences gained in other cities, where the importance of good situation analysis and urban producer participation for effective policy making had become evident. In Governador Valadares (Brazil), for example, the Urban Management Programme supported land use mapping and identification of urban agriculture to provide a better basis for land use planning and management. Large areas of vacant and potentially productive land areas were identified through GIS-based mapping and community consultations. The municipal government acted on recommendations from this situation analysis by introducing a property tax reduction by up to $3 \%$ on empty lots given over to urban agriculture production for a minimum of two years. Similarly in Rosario, Argentina, secure access to land was identified as a key priority issue by community gardeners. Realizing that there was no communication between the gardeners and municipal actors, as well as among various municipal actors involved, multistakeholder communication and planning helped solve apparently conflicting interests. The Servicio Público de la Vivienda (SPV_-public housing authority), for example, whose mandate was to prevent squatters from permanently settling on property intended for future construction, began to see the advantage of formally ceding the land for a limited time to gardeners to tend it (Guenette, 2006a and 2006b).

\section{Implementation of the MPAP in Lima}

The Multistakeholder Policy formulation and Action Planning process in Lima included four stages:

\section{Strengthening Local Capacities}

Decision-makers, municipal and NGO staff, and university representatives participated in awareness-raising activities, policy seminars, and exchange visits to other cities with experience in urban agriculture like Rosario, Argentina. This helped them gain a better understanding of urban agriculture and its effect on food security, incomes, and a greener urban environment, and reinforced their commitment to the multistakeholder planning process. Local stakeholders were also trained in the
MPAP approach, and a local team was formed to implement the following steps in the process. This team included representatives from the local government, researchers and support organizations, and urban farmer leaders.

\section{Situation Analysis}

A participatory situation analysis of urban agriculture was implemented as a basis for further action planning. This situation analysis sought to respond to the following questions:

- What do we understand about urban agriculture in Villa María del Triunfo?

- Where does urban agriculture take place?

- Which stakeholders are involved in urban agriculture (urban producers as well as support organizations)?

- What is the current legal and normative framework for urban agriculture?

- What are potentials and problems for urban agriculture development and how best can it be supported?

In order to respond to these questions, and as part of the situation analysis, a stakeholder analysis was implemented, and the legal and normative frameworks affecting urban agriculture were analyzed and land resources were identified and mapped. In addition and by applying participatory appraisal tools, the variety of urban agriculture systems found in the municipality was studied in order to identify their functions and impacts (positive or negative). Results from the situation analysis were documented (Municipality of Villa María del Triunfo, IPES, \& RUAF, 2006) and shared with all stakeholders involved. As a result of this process, an inventory of probable key issues to guiding the formulation of policies and potential interventions for action were identified, and a joint agreement was reached on the importance of future urban agriculture development for the city: "Urban agriculture in Villa María del Triunfo is recognized as a dynamic activity and integral part of the 
economic and ecological urban system that contributes, based on participation of all actors involved, to rehabilitating vacant spaces, in harmony with the environment and to food security and income generation for its population" (vision on urban agriculture development, Concerted Strategic Plan for Urban Agriculture in Villa María del Triunfo 2007-2011).

\section{Action Planning}

By the end of 2006, a multistakeholder forum on urban agriculture was formed, named the "Urban Agriculture Forum," in which 20 institutions, including the local government, development NGOs, community-based organizations, privatesector organizations, international agencies, and urban producer groups participated. Tasks of the forum included: (1) bridging the communication gap between direct stakeholders and the institutional actors in urban agriculture; (2) functioning as a more permanent platform for information exchange and dialogue; (3) coordinating the planning, implementation, and monitoring of a concerted city agenda on urban agriculture; and (4) stimulating the institutionalization of such activities. The forum was given the mandate of developing a five-year strategic action plan based on a common vision of the development of urban agriculture in the municipality (see above). In a series of forum meetings, a set of policy objectives and related intervention strategies were defined, including proposals for project implementation, training, and research, and the development of a facilitating legal framework for urban agriculture. The strategic action plan was also coordinated with the city's economic development plan. By the end of 2007 , the plan was formally approved by all the city council and other stakeholders involved in the forum.

\section{Implementation}

In addition to policy reform, the multistakeholder forum sought to operationalize the City Strategic Plan into the design, budgeting, and operational planning of specific projects under each of the identified key areas. With some co-funding from IPES/RUAF, in 2007-2008 the multistakeholder forum was able to secure over US $\$ 195,000$ to

\section{Strategic Plan For Urban Agriculture (2007-2011)}

The Villa María Strategic Plan on Urban Agriculture aims to contribute to the 2011 city vision for a healthy, productive, and food-secure city. It identifies six key areas for developing urban agriculture:

1. Strengthening the awareness of the urban population on the benefits of urban agriculture

2. Developing technical and managerial (organizational) capacities of urban producers

3. Improving access to and the rational use of water for urban agriculture

4. Improving local production and marketing of urban agriculture

5. Strengthening the institutional and normative framework for developing urban agriculture in the district

6. Facilitating access to information on and financing for urban agriculture.

Source: Municipality of Villa María del Triunfo, IPES, RUAF and the VMT Urban Agriculture Forum (2007). Villa María:

Sembrando para la vida. Plan Estratégico Concertado de

Agricultura Urbana para Villa María del Triunfo (2007-2011). Available at http://www.ipes.org/index.php?option=com content\&view=article\&id=172\&ltemid=104

implement several of its short-term actions as defined in the strategic plan, including:

(a) Strengthening and formalizing an urban agriculture producers' network.

In order to benefit from more coordinated action and a more common voice in interactions with the local government and support organizations, the urban farmers in Villa María were organized on both the neighbourhood and district level. The groups received training in personal relations and organizational management, developed regulations, agreed on organizational principles, and developed a common logo for sale of urban agricultural produce. The producers organization, which obtained legal status from the local government in 2008 (Municipal Resolution No. 060-2008/ 
MVMT), played a critical role in lobbying for continued political support for urban agriculture after changes in the municipality's mayor and municipal council took place in 2006.

\section{(b) Setting up five community garden units and strengthening enterprise development in urban agriculture}

In collaboration and with financial support of Red Electrica Peru (an electric utility company), FAO and the municipality, five community gardens were established on vacant land located under electrical power lines. As construction and other urban land uses under these lines are prohibited, access to and tenure of land for urban farming is ensured through renewable leases from the electricity company. Participating farming households produce for home consumption as well as sale of surplus production. To this date, a total of 45 families (225 persons) have benefited directly from this intervention. In addition to supporting these more social forms of urban agriculture, a project with peri-urban producers in Villa María was implemented to analyse and develop more commercial urban agriculture enterprises. With support of IDRC-Canada and IPES/RUAF, a peri-urban producers' organization with 59 household members is being supported to improve production and marketing of aloe vera. The technical and organizational capacities of the producers are strengthened in urban farmer field schools. In addition, the project supports the organization in its efforts to secure access to the land on which they are developing their activities.

\section{(c) Urban agriculture week}

In August 2007, the first urban agriculture week was organized to increase awareness of and enhance public support for urban agriculture. During the week, the urban gardens can be visited, short workshops and discussion groups are organized, videos are shown, and a variety of local produce is sold. Since 2007, the urban agriculture week has been organized every year.

\section{(d) Municipal ordinance on urban agriculture}

As urban agriculture had lacked specific regulation in the district up to now, a municipal ordinance on urban agriculture was drafted and approved in 2007. Among other things, the ordinance recognizes urban agriculture as a permanent and legitimate activity in the district; creates a specific government entity for urban agriculture (a subdepartment) with human and financial resources to strengthen urban agriculture; provides for the inclusion of urban agriculture in land use plans; and calls for technical and financial assistance to be given to producers. Today, the municipality has legalized access by urban producer groups to public (municipal) land for the development of community gardens. This has been carried out under a municipal authorization for land use based on the Municipal Urban Agriculture Ordinance mentioned here.

\section{Results and lessons learned}

Results of the MPAP as illustrated above demonstrate that there is wide consensus among decision-makers and other stakeholders that urban agriculture contributes to the city's policy goals of reducing hunger and poverty and generating local economic development. Formerly vacant land areas in the city, such as those located under highvoltage power lines or on steep slopes, have been transformed into productive green spaces, contributing not only to greater food security and increased income, but also to a more liveable urban environment.

The municipal ordinance has provided urban agriculture with legitimacy and facilitated its integration in the city's economic development and land use plans. The urban agriculture program is now a permanent structure under the Department for Local Economic Development with five permanent staff and an annual budget of US $\$ 55,000$. In order to enhance the development of concrete activities in urban agriculture, it is essential to institutionalize urban agriculture. This includes providing it an institutional home and incorporating it into the normative frameworks and strategic development and land use plans of the city, and to develop specific policies (municipal ordinances, laws, regulations) for urban agriculture that facilitate and regulate its practice. 
It has proven crucial to combine a process of strategic planning and policy formulation with implementation of actions that produce tangible results and help to reinforce the commitment and participation of the actors, and especially the urban farmers, involved. The development of pilot projects or actions that have an impact in the short term may also help create a positive environment for more complex and long-term processes.

The multistakeholder forum that was formed guarantees continuous dialogue among involved stakeholders and oversees the implementation of the Strategic Plan for Urban Agriculture. The forum still continues to function in 2010, even after direct IPES/RUAF support ended in 2008.

Continued awareness-raising and information dissemination among decision-makers and other stakeholders of the potential of urban agriculture to alleviate hunger and poverty, however, remains key to promoting and institutionalizing policies friendly to urban agriculture, especially to counteract possible negative consequences of change in technical and municipal staff. Strategies to do so could include the organization of policy seminars, exchange visits, and fairs and field days such as those organized during the urban agriculture week.

To overcome inevitable changes in levels of political support, it is also necessary to strengthen the organizational, managerial, technical, and networking capacities of urban farmers.

Consolidated and strong organizations are better equipped to speak clearly and in unison with local authorities. The organization and empowerment of urban farmers in Villa María proved vital to sustaining the multistakeholder planning process after municipal elections and political changes took place.

Finally, it will be important to regularly revise and update the City Strategic Action Plan, by defining priorities for the coming years and eventually including additional policy goals and strategies. After all, while implementing the plan, new strategic needs or opportunities for developing urban agriculture will emerge. Experiences in other cities showed that in other cases, the initial plan focused mainly on certain types of urban agriculture (for example, the promotion of home and community gardening) and needed to be broadened to include strategies for developing other types of more commercial urban agriculture (Dubbeling et al., 2010).. This might also be relevant for Villa María del Triunfo. In order to do so, monitoring the implementation of the plan and its results will be crucial.

Another aspect that may require more attention and monitoring in the future are concerns about the possible negative effect of electromagnetic fields for gardens under power lines. For example, there is a "prudent avoidance" policy in place in Toronto, Canada, for hydro corridors (City of Toronto, 2008). The policy seeks to specifically minimize children's exposure to electromagnetic fields (EMFs) using easily achievable, low- or nocost measures. When planning new gardens and other beneficial uses in hydro corridors, the policy requires that the city measure EMF levels and predict the average time children might spend in the corridor so as to determine the best location for the garden. Toronto Public Health is currently developing an EMF protocol to further guide the city's compliance with this policy Jodi Callan, personal communication, 2010).

\section{References}

Baker, J. (2008). Impacts of financial, food and fuel crisis on the urban poor. In Directions in urban development. Washington, DC: World Bank, Urban Development Unit.

Centro Internacional de la Papa-CIP. (2007). Impacts of urban agriculture - Highlights of Urban Harvest research and development, 2003-2006. Lima, Peru: Author.

City of Toronto. (2008). Staff report: Reducing electromagnetic field exposure from bydro corridors, Toronto, Canada. http://www.toronto.ca/health/hphe/ pdf/emf boh report.pdf

Cole, D., Lee-Smith D., \& Nasinyama G. (Eds.) (2008), Healthy city harvests: Generating evidence to guide policy on urban agriculture, Lima, Peru: CIP and Makarere University Press.

Dubbeling, M., de Zeeuw, H., \& van Veenhuizen, R. (Eds.). (2010, forthcoming). Cities, poverty and food; 
Multistakeholder policy formulation and action planning.

Rugby, UK: Practical Action Publishing.

Faysse, N. (2006). Troubles on the way: An analysis of the challenges faced by multistakeholder platforms. Montpellier, France: CIRAD.

Guenette, L. (2006a). A city hooked on urban farming. Case Study No 6. Growing Better Cities. Ottawa, Canada: IDRC.

Guenette, L. (2006b). Gardening takes root in Governador Valadares. Case study No 4. Growing Better Cities. Ottawa, Canada: IDRC.

Hemmati, M. (with contributions from F. Dodds, J. Enayati \& J. McHarry). (2002). Multi-stakeholder processes for governance and sustainability: Beyond deadlock and conflict. London: Earthscan.

Instituto Nacional de Estadística et Información (INEI). (2005). Censo Nacional 2005 de población y de vivienda, Lima, Peru: Author.

Mendes, W. (2008). Implementing social and environmental policies in cities: The case of food policy in Vancouver, Canada. International Journal of Urban and Regional Research, 32 (4). doi:10.1111/j.1468-2427.2008.00814.x

Mougeot, L. J. A. (Ed.). (2005). AGROPOLIS The social, political and environmental dimensions of urban agriculture. London: Earthscan.

Municipality of Villa María del Triunfo, IPES, and RUAF. (2006). Villa María, Sembrando para la vidaSituación, limitaciones, potenciales y actores de la agricultura urbana en Villa Maria del Triunfo (2007-2011), Lima, Peru: Authors.

Municipality of Villa María del Triunfo, IPES, RUAF, \& the VMT Urban Agriculture Forum. (2007). Villa
María: Sembrando para la vida. Plan Estratégico Concertado de Agricultura Urbana para Villa María del Triunfo (2007-2011), Lima, Peru: Authors.

Merzthal, G. (2006). Integration of urban agriculture in municipal agendas, experiences from Lima, Peru. In Urban Agriculture Magazine No 16: Formulating effective policies on urban agriculture. Leusden, The Netherlands: RUAF Foundation.

Partners and Propper. (2004). Verslag Afronding 'initiatieffase' opstelling regeling burgerparticipatie gemeente Westervoort. Vught, The Netherlands.

Redwood, M. (2009). Agriculture in urban planninggenerating livelihoods and food security. London: Earthscan/IDRC.

Redwood, M. (2010). Commentary: Food price volatility and the urban poor, In C. J. Pearson, S. Pilgrim, J. Pretty (Eds.), Urban agriculture: Diverse activities and benefits for city society (pp. 5-6). London: Earthscan.

UN FAO. (2008). Urban agriculture for sustainable poverty alleviation and food security. Paper prepared for the World Bank (unpublished), Rome.

UN Habitat \& UNEP. (1999). Institutionalising environmental planning and management process. Sustainable Cities Programme. Nairobi: Authors.

van Veenhuizen, R. (Ed.). (2006). Cities farming for the future: Urban agriculture for green and productive cities. Los Banos, The Philippines: RUAF Foundation, IDRC, and IIRR.

Warner, J. (Ed.). ( 2007). Multistakeholder platforms for integrated water management. Aldershot, UK: Ashgate Publishing. 